\title{
Soil macrofauna in areas with different ages after Pinus patula clearcutting
}

\author{
Esteban Tulande-M., ${ }^{1, *}$ José Ignacio Barrera-Cataño ${ }^{1,2}$, Carlos Eduardo Alonso-Malaver, ${ }^{1,3}$, \\ Carlos Morantes-Ariza ${ }^{2}$, Sofía Basto ${ }^{2}$
}

Edited by

Juan Carlos Salcedo-Reyes

(salcedo.juan@javeriana.edu.co)

1. Escuela de Restauración Ecológica,

Departamento de Biología,

Facultad de Ciencias,

Pontificia Universidad Javeriana,

Carrera 7 No. 43-82,

Bogotá, Colombia.

2. Unidad de Ecología y Sistemática

(UNESIS), Departamento de Biología,

Facultad de Ciencias,

Pontificia Universidad Javeriana,

Carrera 7 No. 43-82,

Bogotá, Colombia.

3- Departamento de Estadística,

Facultad de Ciencias,

Universidad Nacional de Colombia,

Carrera 30 No. 45-03,

Bogotá, Colombia.

*etulande@javeriana.edu.co

Received: 07-06-2017

Accepted: 26-09-2018

Published on line: 26-12-2018

Citation: Tulande-M E, Barrera-Cataño JI, Alonso-Malaver CE, Morantes-Ariza

C, Basto S. Soil macrofauna in areas with different ages after

Pinus patula clearcutting,

Universitas Scientiarum, 23 (3): 383-417, 2018.

doi: 10.11144/Javeriana.SC23-3.smia

Funding:

Corporación Autónoma Regional

de Cundinamarca (CAR) and

Pontificia Universidad Javeriana (PUJ)

to J.I.B-C. and S.B.

\section{Abstract}

In Andean high montane areas, the establishment of exotic tree forests changes the soil dynamics and its biodiversity. Soil macrofauna act as indicators of ecosystem successional processes, and may have an important role in ecological restoration processes after clearcutting exotic tree plantations. The aim of the present study was to understand how soil macrofaunal assemblies change in areas with different ages post clearcutting of Pinus patula, and to identify the soil physico-chemical variables that better explain these variations. The macrofauna in a high montane forest was evaluated along with that of three areas with different ages post clearcutting: $0,2.5$, and 5 years after clearcutting (Yac). The effect of soil physico-chemical variables on macrofauna abundance was also evaluated. Macrofauna composition changed after clearcutting. Macrofauna abundance, richness, and diversity were lower in the 0 Yac area than in the other areas. Moreover, the macrofuna similarity to the reference forest did not increase with the years after clearcutting. This is due to the changes in soil characteristics, triggered by clearcutting. Slope, temperature, bulk density, real density, loam, $\mathrm{pH}, \mathrm{P}, \mathrm{Na}$ and $\mathrm{K}$ were the soil variales with a positive effect on the macrofauna abundance. These physico-chemical variables should be considered when designing restoration plans for Andean forest ecosystems. Moreover, Diplopoda, Coleoptera and Chilopoda might be useful to monitor and evaluate restoration processes after Pinus spp. clearcutting, because of their high abundance, diversity and relationship with environmental conditions.

Keywords: Andes; tropical montane forest; restoration ecology; soil macrofauna.

\section{Introduction}

Tropical montane forests, specifically high Andean ones, entail one of the most important ecosystems on Earth due to their high biodiversity [1, 2] and their key role providing vital ecosystem services to human populations: 
water, food, and climate regulation. However, high montane forests are one of the most threatened ecosystems and, thus, are target of conservation and restoration efforts promoted in recent years [3-7]. The Andean region of Colombia is the most densely populated of the country. This has led to extensive transformations of its forests. In consequence, only $10 \%$ of the original Andean forests are still conserved and less than $5 \%$ of these are specifically high montane forests $[2,5,8]$. For over a century, Colombian high Andean forests have been transformed into exotic tree plantations. The exotic pine Pinus patula is one of the tree species most used for this purpose $[4,9,10]$.

Compared to areas with semi-natural high montane forest vegetation, the soil environment in pine plantations experiences unique dynamics. Pine needles deposited on the soil are rich in lignin and take longer to degrade. This results in the accumulation of a layer of scarcely degraded organic matter $(\mathrm{OM})$. This type of OM is characteristic of coniferous forests [11-14]. Moreover, litter produced by species of Andean forests has a high $\mathrm{N}$ and $\mathrm{C}$ content, thus its degradation and nutrient turnover rate is accelerated [15-18]. In addition, the low temperature and humidity of the Andean region decreases the speed of OM degradation in the surface horizon. This leads to accumulation of $\mathrm{OM}$ in the top soil [19-23]. OM is the basis and the main source of energy of the soil's food chain [24-27], therefore, any change in OM forms will have strong effects on the entire soil biota, mainly on its macrofauna, because their digestive system lacks of lignolytic enzymes to process material with highly polymerized polysaccharides [28-32].

Edaphic macrofauna entail all soil invertebrates larger than $2 \mathrm{~mm}$ belonging to different taxonomic groups. Macrofauna are essential elements of the edaphic ecosystem because of their size, whereby they have a unique role in the ecosystem, specifically by regulating soil dynamics such as nutrient cycling and controlling pests and diseases [33-36]. Moreover, they have an indirect effect on $\mathrm{OM}$ mineralization and humification processes by enhancing functions of the edaphic meso and microfauna [37-39]. This link with ecosystem functioning makes them indicators of soil quality $[40,41]$, disturbance $[24$, 42, 43] and successional processes [44-46]. For these reasons, in the last decade, there has been a growing interest in studying their role in ecological restoration processes [38, 47-50].

In Colombia, studies have investigated the macrofauna composition of Andean forests, exotic tree species plantations, and agricultural lands, revealing a higher soil macrofauna diversity in Andean forests compared to both conifer plantations and agricultural areas [51-59]. However, there are no studies investigating macrofauna succession processes nor the relationships between 
macrofauna and physico-chemical variables in areas after clearcutting of $P$. patula. In this study we addressed the questions on how do soil macrofauna composition, structure and function vary among areas with different post clearcutting ages of Pinus patula, and which physico-chemical soil variables better explain the possible variation. To answer these questions, we evaluated the composition and structure of the edaphic macrofauna of three high montane successional areas and a high Andean forest patch. Our leading hypothesis was that areas that experienced pine clearcuttings earlier, and have no recent input of needles onto their soils, were more suitable for the arrival of different macrofauna groups. Consequently, we expected that the similarity with the Andean forest patch will increase with the time elapsed after clearcutting.

\section{Materials and methods}

Study site

The survey was conducted at the Parque Forestal Embalse del Neusa (PFEN), a forest reserve established around an artificial lake in the Cundinamarca department, located at 3100 masl on the eastern Cordillera of Colombia. The average annual temperature in this forest reserve is $10.5^{\circ} \mathrm{C}$, rainfall regime is bimodal, and average precipitation is $1025 \mathrm{~mm} /$ year. The study site is humid (40-70), according to the De Martonne climatic classification method. Soils are classified by their textural class as Silty Clay Loam [60], with predominance of silt and clay. This kind of soil is characterized by its high water retention capacity, high organic matter content, and drainage problems [61]. In 1950, the $P$. patula plantation was established around an artificial reservoir in the PFEN to avoid any sedimentation and erosion processes that could affect the waterbody [62]. However, because the plantations never received silvicultural management, they caused several environmental problems; consequently, in 2009 the environmental authority Corporación Autónoma Regional de Cundinamarca decided to carry out the removal of these plantations, and to launch an ecological restoration program.

Three areas with different post-clearcutting ages (years after clearcutting - Yac) were selected to perform the samplings: Laureles ( 0 Yac), Chapinero (2.5 Yac) and Guanquica (5 Yac). In addition, a high montane Andean forest patch was selected as the reference forest (RF) (Fig. 1). Since the studied areas are of different sizes, the smallest one ( 0 Yac $12.6 \mathrm{ha}$ ) was chosen to standardize the grid dimension. Then, through satellite imaging, a grid of $300 \mathrm{~m}^{2}$ and 316 points was located, each point was separated by a distance of $20 \mathrm{~m}$ (Suppl. 1A). The same grid dimension was used to locate the points in the other areas (2.5 Yac, 5 Yac and RF) also by using satellite images (Suppl. 1B-D). After grids were located, 12 points were randomly selected in each area to establish the experimental plots $\left(10 \mathrm{~m}^{2}\right)$. 


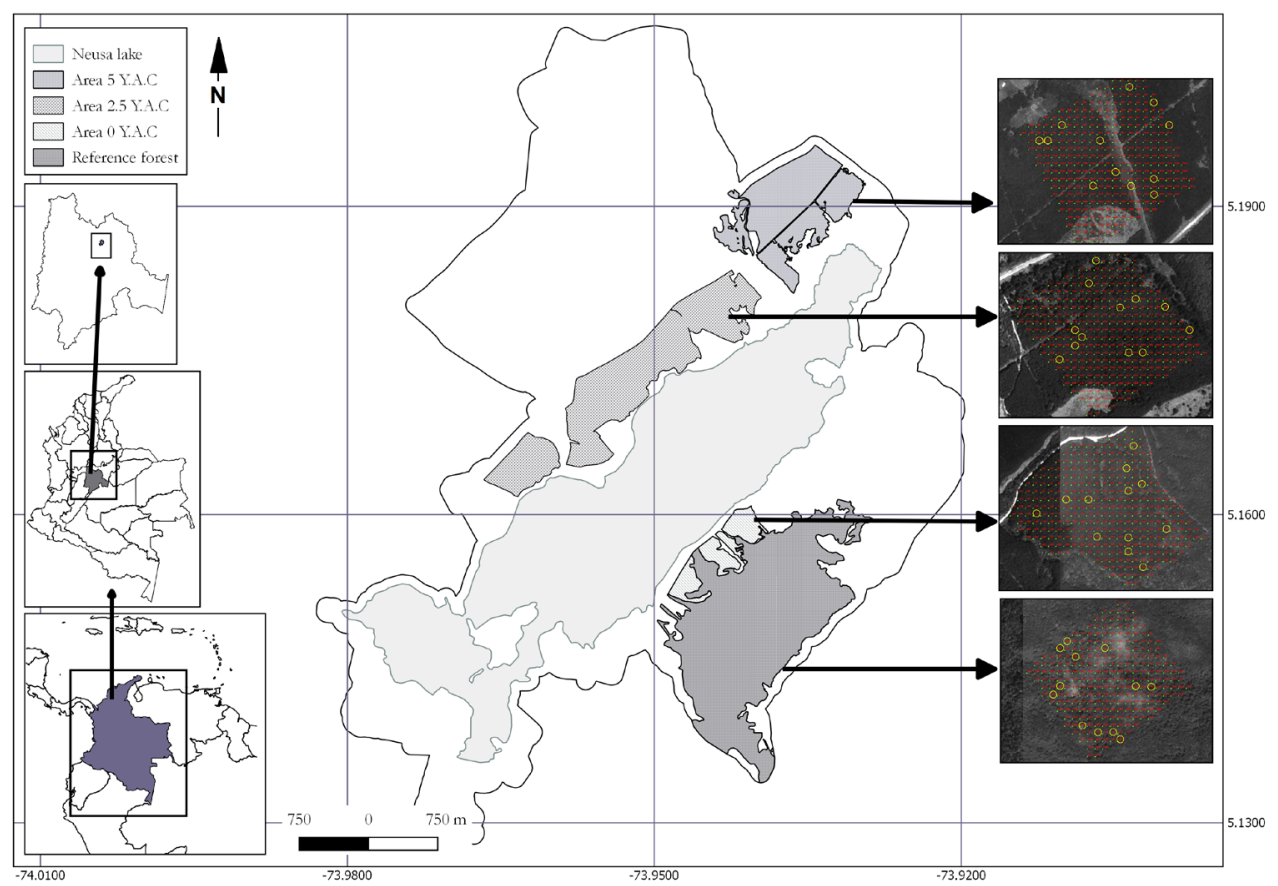

Figure 1. Study site location. The figure shows the reference forest and the three areas with different post clearcutting ages (years after clearcutting (Yac)): 1) 0 Yac, 2) $2.5 \mathrm{Yac}$ and 3) 5 Yac. Yellow circles indicate the localization of sampling points within each area.

The 0 Yac area is almost lacking any vegetation, and only a few pioneer species are present: Phytolacca bogotensis and Mueblenbeckia tamnifolia. The soil in this 0 Yac area is mostly covered by $P$. patula leftovers (needles, stumps, branches and some logs). Vegetation in the 2.5 Yac area is dominated by the shrub Rubus floribundus and the herbaceous plant Holcus lanatus, the latter is also the dominant species in the 5 Yac area; in this area there is little accumulation of litter on the ground, which consists mainly of herbaceous leaves. The $\mathrm{RF}$ is a remnant of tropical high montane forest, with a perhumid regime. It is dominated by Weinmannia tomentosa, however, other species such as Chusquea scandens, Drimys granadensis and Myrsine coriacea are common in this ecosystem.

\section{Soil macrofauna sampling}

Sampling of edaphic macrofauna was carried out in July 2014, using the tropical soil biology and fertility method (TSBF), which consists of extracting $25 \times 25 \times 20 \mathrm{~cm}$ soil monoliths [41, 63]. In total, 12 monoliths per area and 48 in total were obtained. Each monolith was stored in a plastic bag 
to avoid drying. Later, organisms were manually extracted and preserved in $96 \%$ alcohol. Oligochaetes and larvae were previously fixed in $5 \%$ formaldehyde for 72 hours. Indicator morphospecies were identified to the narrowest possible taxonomic level according to existing identification guides $[64][65][66][67][68][69][70]$.

\section{Soil sampling and physico-chemical measurements}

Inside each $10 \mathrm{~m}^{2}$ plot of every study area ( 0 Yac, $\left.2.5 \mathrm{Yac}, 5 \mathrm{Yac}, \mathrm{RF}\right)$, a soil sample composed of 3 subsamples was randomly extracted by using the cylinder method [71]. Subsequently, $1 \mathrm{~kg}$ of each composite sample was stored in a plastic bag and transported to the Instituto Geográfico Agustín Codazzi [72]. The physical variables evaluated were: 1) slope; 2) bulk density, which was determined by extracting unchanged soil samples at soil depth of $20 \mathrm{~cm}$ by using the paraffin cylinder method [73]; 3) real density that was measured by the pycnometer method [74]; 4) texture, which was determined through the Bouyoucos method by using a hydrometer $[73,75]$; 5) porosity, that was determined by the mercury porosimetry technique [76]; and 6) temperature, which was measured with a soil thermometer in the monolith.

The chemical variables evaluated were: 1) $\mathrm{pH}$, measured with a potentiometer, for which a water solution (1:1) was prepared [76]; 2) interchangeable acidity, and 3) saturation percentage of interchangeable acidity (S.I.A) were determined by using $1 \mathrm{M}$ potassium chloride extraction and quantification by volumetric titration [76]; 4) soil organic carbon (SOC) was determined by the Walkley-Black volumetric titration [77]; 5) total nitrogen was obtained by Kjeldahl potentiometric titration [76]; 6) cation exchange capacity (CEC) [78]; 7) percentage base saturation (BS) and 8) total bases $\mathrm{Ca}, \mathrm{Mg}, \mathrm{K}, \mathrm{Na}(\mathrm{BT})$ were determined by $1 \mathrm{M}$ ammonium acetate extraction ( $\mathrm{pH} 7$ ) and quantification by volumetric titration [76]; and 9) available phosphorous $(\mathrm{P})$ was determined by using the extraction method with Bray II solution and by spectrophotometric quantification in the visible range [76] (Table 1).

\section{Statistical analysis}

To characterize each edaphic community, the richness of orders and their abundance, as the number of individuals, were quantified. Orders with fewer than three individuals were excluded from the statistical analysis (Lithobiomorpha, Psocoptera, Mantodea and Pseudoscorpiones). The alpha diversity was measured using the Shannon-Wiener index and species evenness was calculated with the Pielou's evenness index, as implemented in the R-package Vegan [67]. Macrofauna data were tested for normality with 
Table 1. Physico-chemical variables measured in the reference forest (RF), in an area with less than one year after clearcutting $P$. patula plantation ( $O \mathrm{Yac}$ ), an area with 2.5 years after clearcutting $(2.5 \mathrm{Yac})$, and an area with 5 years after clearcutting (5 Yac). Standard deviation (Sd).

\begin{tabular}{|c|c|c|c|c|c|c|c|c|}
\hline Area & \multicolumn{2}{|c|}{$0 \mathrm{Yac}$} & \multicolumn{2}{|c|}{$2.5 \mathrm{Yac}$} & \multicolumn{2}{|c|}{5 Yac } & \multicolumn{2}{|c|}{ RF } \\
\hline Variables & Mean & Sd & Mean & Sd & Mean & Sd & Mean & Sd \\
\hline Slope & 7.33 & 3.551 & 10.58 & 6.244 & 8.00 & 8.268 & 11.00 & 12.225 \\
\hline Temperature $\left(\mathrm{C}^{\circ}\right)$ & 12.59 & 0.439 & 12.84 & 0.497 & 12.78 & 0.645 & 10.56 & 0.147 \\
\hline Bulk density ( $\mathrm{g} / \mathrm{cm} 3)$ & 0.26 & 0.065 & 0.36 & 0.065 & 0.34 & 0.038 & 0.23 & 0.032 \\
\hline $\mathrm{pH}$ & 4.01 & 0.231 & 4.63 & 0.231 & 4.51 & 0.144 & 3.76 & 0.151 \\
\hline I.A. $(\mathrm{cmol} / \mathrm{kg})$ & 13.31 & 4.798 & 5.55 & 1.908 & 7.40 & 1.511 & 22.82 & 2.681 \\
\hline S.I.A. $\%$ & 93.93 & 2.223 & 65.97 & 17.003 & 73.60 & 15.553 & 97.09 & 0.394 \\
\hline $\mathrm{SOC} \%$ & 27.93 & 4.892 & 13.67 & 3.686 & 15.53 & 2.794 & 30.32 & 1.453 \\
\hline Total nitrogen \% & 1.34 & 0.194 & 0.77 & 0.247 & 0.84 & 0.179 & 1.51 & 0.138 \\
\hline $\mathrm{CEC}(\mathrm{cmol} / \mathrm{Kg})$ & 82.76 & 11.547 & 49.78 & 9.878 & 51.00 & 8.058 & 90.32 & 10.830 \\
\hline $\mathrm{Ca}(\mathrm{cmol} / \mathrm{kg})$ & 0.10 & 0.079 & 1.21 & 0.840 & 1.08 & 0.635 & 0.08 & 0.058 \\
\hline $\mathrm{Mg}(\mathrm{cmol} / \mathrm{kg})$ & 0.16 & 0.067 & 1.11 & 0.908 & 1.15 & 1.270 & 0.12 & 0.068 \\
\hline $\mathrm{K}(\mathrm{cmol} / \mathrm{kg})$ & 0.42 & 0.107 & 0.44 & 0.291 & 0.56 & 0.375 & 0.33 & 0.075 \\
\hline $\mathrm{Na}(\mathrm{cmol} / \mathrm{kg})$ & 0.10 & 0.087 & 0.08 & 0.054 & 0.06 & 0.029 & 0.15 & 0.067 \\
\hline BS \% & 0.95 & 0.267 & 6.24 & 4.067 & 5.88 & 4.624 & 0.76 & 0.118 \\
\hline $\mathrm{P}(\mathrm{mg} / \mathrm{kg})$ & 8.03 & 1.414 & 9.88 & 5.607 & 9.13 & 2.351 & 8.39 & 3.159 \\
\hline Real density (g/cm3) & 1.06 & 0.732 & 2.12 & 0.180 & 2.03 & 0.186 & 1.77 & 0.075 \\
\hline Sand $(\%)$ & 9.38 & 2.245 & 13.82 & 6.708 & 10.54 & 2.117 & 14.56 & 4.228 \\
\hline Lime $(\%)$ & 52.10 & 10.484 & 47.38 & 18.985 & 50.59 & 15.163 & 45.29 & 6.750 \\
\hline Clay (\%) & 38.52 & 11.670 & 38.79 & 18.693 & 38.87 & 14.166 & 40.15 & 7.390 \\
\hline Porosity & 59.98 & 26.099 & 82.80 & 2.934 & 83.24 & 3.010 & 87.12 & 1.941 \\
\hline
\end{tabular}

the Shapiro-Wilk test and showed a significant deviation from normality (Shapiro-Wilk < 0.05). Therefore, the Kruskal-Wallis test $(H$ : Chi square value; $P$ : significance value; $\mathrm{n}$ : sample size) was used to compare the Shannon and Pielou indices among groups. Pairwise comparisons were used to identify significant differences between areas. Moreover, in order to quantify the compositional dissimilarity between areas the Bray-Curtis dissimilarity index and Ward method were used; complete-linkage was implemented as clustering technique. The selection of indicator species in each zone was carried out by using the indicator value index (Ind.Val) [79], using the R-package Labdsv [80]. All statistical analysis were conducted in R [81]. 
Due to pseudoreplication (lack of spatial replicates per site) among the plots from each area, a non-parametric nested manova [82] was performed using the R-package BiodiversityR [83] with 100000 random permutations. Because there was not a significant effect of plots on macrofauna abundance $(\mathrm{F}=0.00124 ; \mathrm{P}>0.05)$, by using generalized linear models (GLMs) for multivariate abundance data [84], the effect of soil physico-chemical variables was evaluated on morphospecies abundance in each of the four areas. GLMs were fitted using the R-package Mvabund [85]. In order to prevent multicollinearity, an individual multicollinearity diagnostic was performed by using the variance inflation factor (VIF) with the R-package mctest [86], as well as a correlation analysis on soil physico-chemical data. $\mathrm{pH}$, interchangeable acidity (A.I), soil organic carbon (CO), nitrogen (N), cation exchange capacity (CEC), Calcium (Ca), Magnesium (Mg), Potassium (K), Sodium ( $\mathrm{Na}$ ), and percentual base saturation (BT). Clusters of variables showing collinearity and high correlation were discarded from the regression analysis. Then, a single variable from each cluster was included in the models. However, soil $\mathrm{pH}$ showed a weak correlation with $\mathrm{Na}$ and $\mathrm{K}$, therefore, all three variables from this cluster were included in the analysis. GLMs, with the Gaussian error distributions, included the explanatory variables: slope, temperature, bulk density, real density, loam, $\mathrm{pH}, \mathrm{P}, \mathrm{Na}$ and $\mathrm{K}$.

\section{Results and discussion}

We collected a total of 3591 individuals and 24 orders, among which Diptera, Polydesmida, Coleoptera and Isopoda were the most abundant (Table 2). Abundance was significantly lower in the 0 Yac site than in the other sites (RF, 2.5 and $5 \mathrm{Yac})(\mathrm{K}-\mathrm{W}, \mathrm{H}=11 ; \mathrm{P}=0.01$; $\mathrm{n}=48)$ (Table 3, Fig. 2). This was an expected result because saprophagous groups from the macrofauna show difficulty processing material with high lignin content [28-32]. Consequently, richness and diversity were lowest in the 0 Yac (K-W, $\mathrm{H}=28.3$; $\mathrm{P}<0.00001 ; \mathrm{n}=48 ; \mathrm{K}-\mathrm{W}, \mathrm{H}=32.4 ; \mathrm{P}<0.00001 ; \mathrm{n}=$ 48 , respectively). In addition, $90 \%$ of the individuals recorded in this area were Dipteran (family Sciaridae) larvae, and $9 \%$ to Coleoptera larvae of species Ancognatha ustulata and A. scarabaeioides. These insects occurr in this area because of their dispersal capacity; as despite their larvae having little mobility, adults have flight capacity [87, 88]. Neita-Moreno \& Morón [89] reported that Ancognatha larvae feed mainly on organic matter, but also can feed on vegetation; this versatility in their feeding sources allows Ancognatha to thrive in 0 Yac. Moreover, these larvae were the largest bodied individuals collected, and according to Kalinkat et al. [90] the largest soil organisms are more diet-flexible. These findings agree with those by [91], who recorded that during the first years after clearcutting, saprophagous specialists were most 
Table 2. Abundance of each of the 24 soil macrofauna orders recorded in the reference forest $(\mathrm{RF})$, in an area with less than one year after clearcutting $P$. patula plantation ( $0 \mathrm{Yac}$ ), an area with 2.5 years after clearcutting $(2.5 \mathrm{Yac})$, and an area with 5 years after clearcutting $(5 \mathrm{Yac}) .{ }^{*}$ : most abundant orders of each area.

\begin{tabular}{lccccc}
\hline Order & $\mathbf{0}$ Yac & $\mathbf{2 . 5}$ Yac & $\mathbf{5}$ Yac & RF & Total \\
\hline Araneae & 1 & 8 & $41^{*}$ & 26 & 76 \\
\hline Blattodea & 0 & $25^{*}$ & 6 & 5 & 36 \\
\hline Coleoptera & 2 & 35 & 58 & $81^{*}$ & 176 \\
\hline Coleoptera-larva & 19 & 78 & $192^{*}$ & 57 & 346 \\
\hline Dermaptera & 0 & 4 & 8 & 0 & 12 \\
\hline Diplura & 1 & 37 & 0 & $122^{*}$ & 160 \\
\hline Diptera & 279 & 195 & $635^{*}$ & 56 & 1165 \\
\hline Geophiliomorpha & 0 & 7 & 0 & $51^{*}$ & 58 \\
\hline Glommeridesmida & 0 & 0 & 0 & $31^{*}$ & 31 \\
\hline Haplotaxida & 0 & $150^{*}$ & 126 & 12 & 288 \\
\hline Hemiptera & 0 & 23 & 10 & 16 & 49 \\
\hline Homoptera & 0 & 1 & 6 & 2 & 9 \\
\hline Hymenoptera & 0 & $116^{*}$ & 3 & 21 & 140 \\
\hline Isopoda & 0 & $173^{*}$ & 51 & 80 & 304 \\
\hline Lepidoptera & 0 & 1 & $4 *$ & 0 & 5 \\
\hline Lithobiomorpha & 0 & 2 & 0 & 0 & 2 \\
\hline Mantodea & 0 & 1 & 0 & 0 & 1 \\
\hline Opiliones & 0 & 13 & 10 & $23^{*}$ & 46 \\
\hline Polydesmida & 0 & $456^{*}$ & 34 & 83 & 573 \\
\hline Psocoptera & 0 & 0 & 0 & 1 & 1 \\
\hline Scolopendromorpha & 4 & 5 & 2 & $31^{*}$ & 42 \\
\hline Spirobolida & 0 & 0 & 0 & 1 & 1 \\
\hline Symphyla & 0 & 0 & 6 & $62^{*}$ & 68 \\
\hline Pseudoscorpiones & 0 & 0 & 2 & 2 \\
\hline Total & 0 & $\mathbf{1 3 3}$ & $\mathbf{7 6 3}$ & 3591 \\
\hline
\end{tabular}

apt to colonize these areas. Overall, few organisms were collected in the 0 Yac, which explains why, according to the indicator value index (Ind.Val), no single species can be regarded as significant indicator of this area $(\mathrm{P}>0.1)$. 
Table 3. Biodiversity index in the reference forest (RF), in an area with less than one year after clearcutting $P$. patula plantation $(0 \mathrm{Yac})$, an area with 2.5 years after clearcutting (2.5 Yac), and an area with 5 years after clearcutting (5 Yac). Means with different letters indicate significant differences according to the Kruskal-Wallis test $(\mathrm{P}<0.05)$. Standard deviation $(\mathrm{Sd})$.

\begin{tabular}{lcccccccccc}
\hline & \multicolumn{2}{c}{ Abundance } & \multicolumn{2}{c}{ Richness } & \multicolumn{2}{c}{ Shannon } & \multicolumn{2}{c}{ Pielou } \\
\hline Area & Mean & Sd & Mean & Sd & Mean & Sd & Mean & Sd \\
\hline 0 Yac & $38.25 \mathrm{a}$ & 100.9 & $1.75 \mathrm{a}$ & 0.7 & $0.37 \mathrm{a}$ & 0.41 & 0.46 & 0.47 \\
\hline 2.5 Yac & $110.83 \mathrm{~b}$ & 121.22 & $8.33 \mathrm{ab}$ & 3.17 & $1.51 \mathrm{ab}$ & 0.31 & 0.76 & 0.175 \\
\hline 5 Yac & $99.33 \mathrm{~b}$ & 145.72 & $7.83 \mathrm{ab}$ & 2.82 & $1.34 \mathrm{ab}$ & 0.50 & 0.665 & 0.20 \\
\hline Rf & $63.33 \mathrm{~b}$ & 30.16 & $12.6 \mathrm{~b}$ & 1.7 & $2.20 \mathrm{~b}$ & 0.190 & 0.88 & 0.47 \\
\hline
\end{tabular}

Species richness and Shannon index were significantly higher in the forest than in the other sites $(\mathrm{K}-\mathrm{W}, \mathrm{H}=28.3 ; \mathrm{P}<0.00001 ; \mathrm{n}=48 ; \mathrm{K}-\mathrm{W}, \mathrm{H}=32.4$; $\mathrm{P}<0.00001 ; \mathrm{n}=48$, respectively). These results agree with other studies in Colombia [51-59]. In contrast, Pielou's index (P) did not show any significant

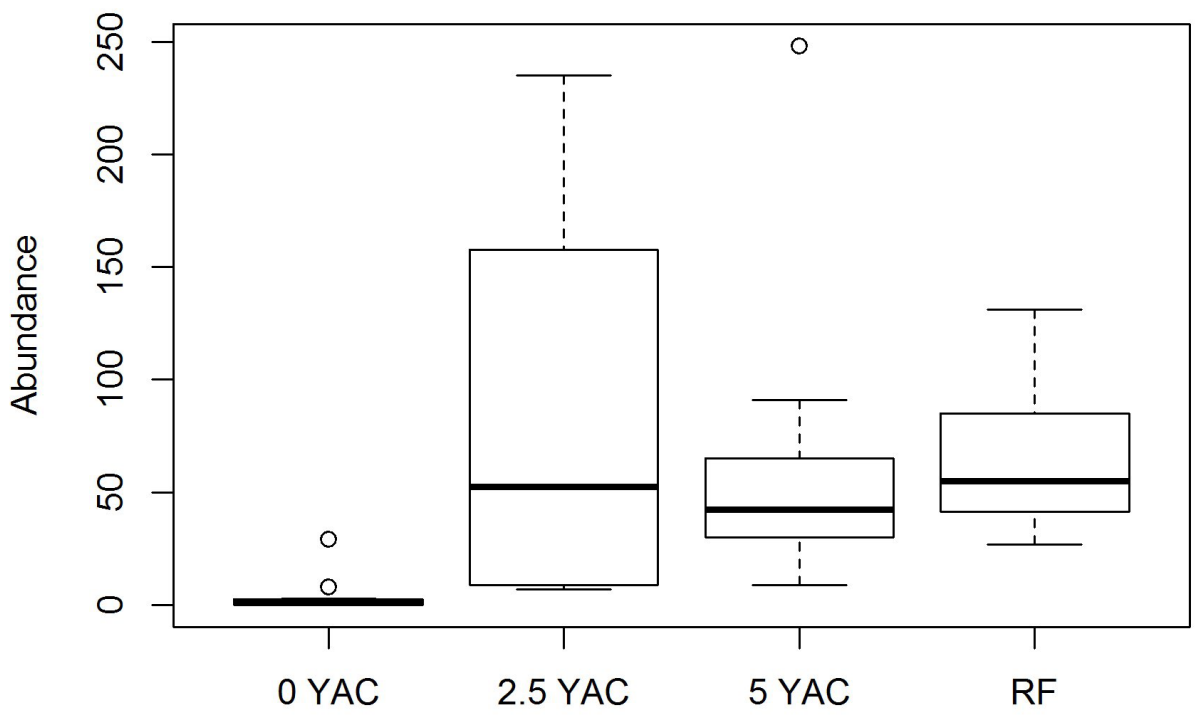

Figure 2. Number of macrofauna individuals in the reference forest $(\mathrm{RF})$, in an area with less than one year after clearcutting $P$. patula plantation $(0 \mathrm{Yac})$, an area with 2.5 years after clearcutting $(2.5 \mathrm{Yac})$, and an area with 5 years after clearcutting (5 Yac). 
differences between areas with several post clearcutting ages $(\mathrm{K}-\mathrm{W}, \mathrm{H}=6.35$; $\mathrm{P}=0.09 ; \mathrm{n}=48$ ), but it was higher and less variable in the forest than the other sites (Table 3). Species richness and diversity were higher in areas with 2.5 and 5 Yac than in 0 Yac, and richness was higher in 2.5 Yac than in the 5 Yac. However, neither abundance nor richness changed significantly between areas $(\mathrm{K}-\mathrm{W}, \mathrm{H}=0.01 ; \mathrm{P}=0.91 ; \mathrm{n}=48 ; \mathrm{K}-\mathrm{W}, \mathrm{H}=0.04 ; \mathrm{P}=0.83$; $\mathrm{n}=48$, respectively). Moreover, the $2.5 \mathrm{Yac}$ showed the highest diversity values after the reference forest. The low diversity recorded for the $5 \mathrm{Yac}$ is probably related to the dominance of two morphospecies, which were the best indicators for this area according to the Ind.Val (Table 4).

According to the Bray-Curtis dissimilarity index, 2.5 and 5 Yac were the most similar to the forest, at the same time these two areas showed the highest similarity between them (Fig. 3). The similarity between 2.5 Yac with the forest is probably related to the OM forms, litter quality, and the transition from an initial OM Mor to a Moder-mull humus type [14]; the latter caused by the decomposition of the needles and the addition of litter from different plant species. After pine clearcutting, the accumulation of needles on the ground stops, and the litter layer-composed mainly of needles-is consumed or processed at a higher rate than any litter layer produced by pioneer plant species, facilitating an overall and gradual litter reduction. Also, in open areas, the litter degradation process advances faster than in the native forest because of direct exposure to solar radiation and rainfall. Consequently, the maintenance of the litter and fermentation layers (OL, OF), typical of the native forest, is prevented. As observed in the $5 \mathrm{Yac}$ area, a change to OM without fermentation layer and with a thin litter but with a high humic layer $(\mathrm{OH})$ occurred. On the other hand, the 0 Yac was the most dissimilar to the 2.5 and 5 Yac areas. Although we did not measure the lignin content of the studied areas, we deduced, based on previous studies [92][93], that fresh pine needles contained a higher amount of lignin in comparison to those that have been degrading for more than two years. This finding agrees with the observation that during the first successional stages after clearcutting, the environmental conditions are constantly changing, producing a very stressful environment for colonizing organisms; therefore, during these stages, species turnover is very slow [94-96].

In all four studed areas, the environmental variables with significant effect on morphotype abundance were slope, temperature, bulk density, real density, loam, pH, P, Na and K (GLM; P $<0.05$ in all cases) (Table 5). Remarkably, areas with slopes greater than $11^{\circ}$ showed the richest macrofauna (Table 2, Fig. 2). This is because slope is one of the factors regulating the amount of $\mathrm{OM}$ and humidity of the soil [97-100]; in this study the highest slope values were 
Table 4. Indicator morphospecies of the reference forest (RF), of an area with less than one year after clearcutting $P$. patula plantation $(O \mathrm{Yac})$, an area with 2.5 years after clearcutting $(2.5 \mathrm{Yac})$, and an area with 5 years after clearcutting (5 Yac). The best indicator species per area is shown in bold. Trophic guild (TF); indicator value index (Ind.Val); relative frequency of species $(\mathrm{F}) ;(*)$ : larvae.

\begin{tabular}{lccccccc}
\hline Area & Morphospecies & Order & Family & FA & $\begin{array}{c}\text { Ind. } \\
\text { Val }\end{array}$ & $\boldsymbol{P}$ & F \\
\hline 2.5 Yac & Batodesmus sp. & Polydesmida & Chelodesmidae & Detritivore & $\mathbf{0 . 5}$ & 0.002 & 6 \\
2.5 Yac & Glossodriluspalenke & Haplotaxida & Glossoscolecidae & Detritivore & 0.47 & 0.001 & 10 \\
2.5 Yac & Blattidae sp. & Blattodea & Blattidae & Detritivore & 0.40 & 0.011 & 12 \\
\hline $\mathbf{5 ~ Y a c}$ & Amphideritus sp. & Coleoptera & Curculionidae & Phytophagous & $\mathbf{0 . 8 2}$ & 0.001 & 17 \\
\hline 5 Yac & Conoderus sp. & Coleoptera* & Elateridae & Phytophagous & 0.76 & 0.001 & 12 \\
\hline 5 Yac & Lycosasp. & Araneae & Lycosidae & Predator & 0.73 & 0.001 & 12 \\
\hline RF & Phaneromerium sp. & Polydesmida & Trichopolydesmidae & Detritivore & $\mathbf{1}$ & 0.001 & 12 \\
RF & Scutigerella sp. & Symphyla & Scutigerellidae & Detritivore & 0.83 & 0.001 & 15 \\
RF & Schendylopsp. & Geophilomorpha & Schendylidae & Predator & 0.75 & 0.001 & 9 \\
RF & Parajapyx sp. & Diplura & Parajapygidae & Predator & 0.74 & 0.001 & 22 \\
\hline
\end{tabular}

recorded in the $\mathrm{RF}$ and the $2.5 \mathrm{Yac}$ areas. Temperature also had a direct effect on detritivorous fauna, in turn it could have affected OM transformation, soil moisture, nutrient retention [93, 98, 101-103] and the microbiological activity [104].

Macrofaunas were affected by several soil chemical features (Table 5). Specifically, the studied macrofauna showed a positive response to the soil's $\mathrm{Na}$ and $\mathrm{K}$ content. $\mathrm{K}$ content has also been correlated with higher decomposition rates [96, 105]. This, in turn, evidences the importance of organic matter layer thickness. In the organic fermentation horizon of the litter layer, $\mathrm{H}_{3} \mathrm{O}^{+}$ ions are released as a result of the hydrolysis of organic acids, explaining the high acidity of the forest $[19,82]$. These ions regulate the solubility of elements such as $\mathrm{P}$ and $\mathrm{S}$, which have been recognized as limiting elements for the Andean vegetation $[1,108,109]$. In addition, $\mathrm{P}, \mathrm{Na}$ and $\mathrm{pH}$ have been previously reported to determine the presence of some macrofauna groups, as Araneae, Coleoptera, Haplotaxida and Isopoda [110, 111]. Therefore, the formation and depletion of the litter layer are key processes to consider in the restoration of areas where clearcutting of exotic species has been carried out. 


\section{Cluster Dendrogram}

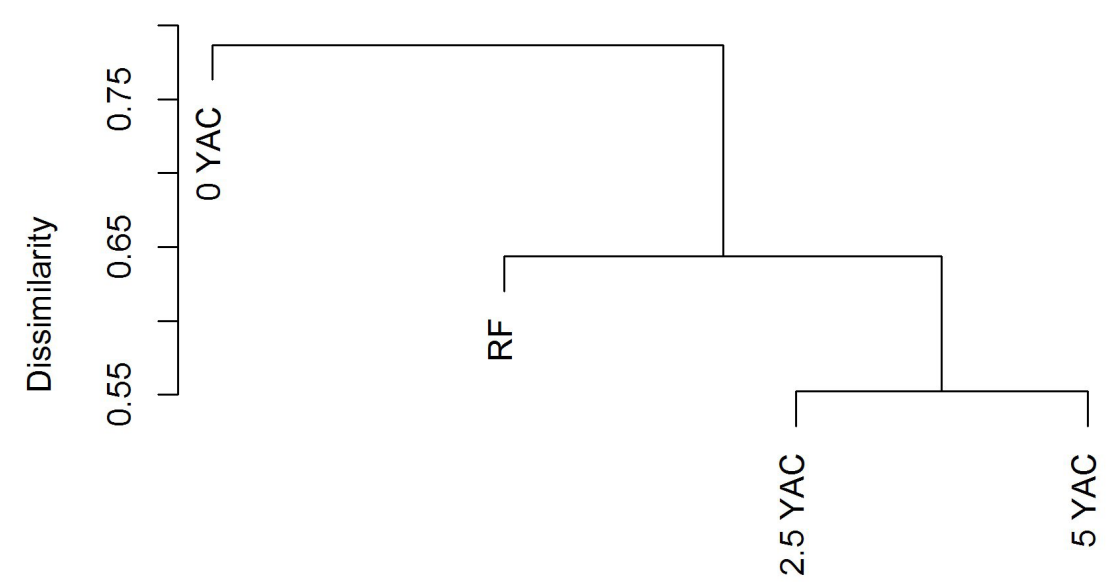

hclust (* , "ward.D2")

Figure 3. Hierarchical clustering analysis based on the Bray-Curtis dissimilarity index. Dendrogram represents soil macrofauna composition similarity between the reference forest $(\mathrm{RF})$, in an area with less than one year after clearcutting $P$. patula plantation $(0 \mathrm{Yac})$, an area with 2.5 years after clearcutting $(2.5 \mathrm{Yac})$, and an area with 5 years after clearcutting (5 Yac).

The importance of the litter layer for the restoration of high Andean forests was recognized through the identification of the morphospecies showing the highest fidelity and specificity to RF. The presence of a symphylan (Ind.Val $=0.83$ ) and a polydesmid of the genus Phaneromerium (Ind.Val $=1$ ) in the RF soil ecosystem reflects the selectivity of these two species for the $\mathrm{RF}$ and highlights the importance of detritivorous fauna in this ecosystem. The genus Phaneromerium is native of South America, its species inhabit exclusively the epigean zone and are characterized by their small size $(<6 \mathrm{~mm})$ [65]. This can be associated with their high population densities in this study. However, two predator morphospecies belonging to the Schendylops and Parajapyx genera were identified as the third and fourth best indicators of the forest (Ind.Val $=0.75$ and 0.74, respectively) (Table 4). Overall, the orders most associated with RF were Polydesmida, Symphila, Diplura, Geophilomorpha, Scolopendromorpha and Glommeridesmida (Table 2).

For the $2.5 \mathrm{Yac}$, the best indicator was a diplopod (Batodesmus sp.) (35\% of the individuals recorded in this area were Dipolopods). A native worm (Glossodriulus palenke) and a cockroach of the Blattidae family were the 
Table 5. Summary of the generalized linear model (GLM) for the morphospecies abundance, as response variable, and physico-chemical soil variables, as the predictors. Results of the statistically best model are shown. $\mathrm{P}<0.001$ ( $* * \%), \mathrm{P}$ $\left.<0.011^{* *}\right), \mathrm{P}<0.05{ }^{*} *$.

\begin{tabular}{lccccc}
\hline & Estimate & s.e. & $\boldsymbol{P}(>$ Wald $)$ & Significance & Response \\
\hline Intercept & 11.2 & \pm 39.4 & 0.000999 & $P<0.001$ & Positive \\
\hline Slope & 7.601 & \pm 0.3 & 0.000999 & $P<0.001$ & Positive \\
\hline Temperature $\left(\mathrm{C}^{\circ}\right)$ & 9.37 & \pm 4.4 & 0.000999 & $P<0.001$ & Positive \\
\hline Loam $(\%)$ & 7.732 & \pm 0.2 & 0.000999 & $P<0.001$ & Positive \\
\hline $\mathbf{P}(\mathrm{mg} / \mathrm{kg})$ & 7.772 & \pm 0.7 & 0.000999 & $P<0.001$ & Positive \\
\hline K $(\mathrm{mg} / \mathrm{kg})$ & 7.891 & \pm 12.4 & 0.000999 & $P<0.001$ & Positive \\
\hline pH & 7.059 & \pm 13.2 & 0.003996 & $P<0.01$ & Positive \\
\hline Bulk Density $(\mathrm{g} / \mathrm{cm} 3)$ & 6.91 & \pm 0.03 & 0.003996 & $P<0.01$ & Positive \\
\hline Na $(\mathrm{mg} / \mathrm{kg})$ & 6.593 & \pm 50.3 & 0.021978 & $P<0.05$ & Positive \\
\hline Real Density $(\mathrm{g} / \mathrm{cm} 3)$ & 6.522 & \pm 9.5 & 0.011988 & $P<0.05$ & Positive \\
\hline Test statistic: & 21.02 & & & & \\
\hline$P$-value: & 0.003 & & & & \\
\hline df & 34 & & & & \\
\hline AIC sum & 5816.267 & & & \\
\hline
\end{tabular}

second and third best indicators of this area. All these groups are saprophagous, so they have an important effect on OM fragmentation and soil structure [112, 113]. The high occurrence of detritivore groups such as Diplopoda, Isopoda and Oligochaeta in this area could be related to the fact that recalcitrant and woody materials enter their own successional process. As the degradation of these materials proceeds, they are more accessible to a larger number of saprophagous groups $[30,114]$. Accordingly, León et al. [18] recorded that the life time of woody material in the soil and the litter produced by $P$. patula in a low montane forest ranges from 2.1 to 2.5 years. Consequently, the arrival or population explosion of macrofauna detritivorous groups could be associated with the time it takes to the remaining material of the $P$. patula plantation to reach its degradation point. During this time, the degrading material is accessible to local saprophagous species. This is an important factor 
to consider for future restoration plans in these areas, because this finding could be interpreted as the first functional change recorded during the early succession of these areas. Also, the increase in saprophagous organisms could indicate the beginning of the heterotrophic phase, characterized by a change from moder type to mull type humus, and an excess in the mineralization rate in comparison to photosynthesis rate [115]. Saprophagous organisms can be enhancers of successional processes due to their role on nutrient cycling and soil formation $[93,116,117]$ and on impacting higher levels of the edaphic food chain, promoting post-disturbance recovery of vegetation $[118,119]$. The importance of diplopods for the Colombian Andean ecosystems had been previously highlighted [120]. Accordingly, the management of pine stumps, logs and needles should be considered for monitoring restoration and conservation projects in this area; the importance of the management of these plant materials, during the early stages of succession, for the edaphic fauna has been previously stated $[94,121]$

For the 5 Yac area, the best indicator was a weevil species of the genus Amphideritus (Coleoptera: Curculionidae), which was more abundant in the larval state, Ind.Val = 0.82 (Table 4). This morphospecies and one belonging to the genus Conoderus (Coleoptera: Elateridae), which was the second-best indicator of this area, were almost absent in the other sites. The third indicator was a spider of the genus Lycosa. These three genera have been associated with grasslands and areas with high anthropogenic intervention [68, 122-126]. Moreover, these morphospecies were not recorded in the forest, and because $5 \mathrm{Yac}$ is the most distant to RF, it is considered that surrounding areas have an important effect on the successional macrofauna process.

Soil compaction is one of the consequences of clearcutting [19]. Consequently, the abundance of groups that spend most of their life cycle under the soil could be reduced. Groups that depend on their ability to dig shelters to avoid dehydration, include Geophilomorpha [64, 127] and Diplopoda [128]. In this study, Geophilomorpha, was almost restricted to the forest in which we recorded the highest proportion of loam and the lowest bulk and real density. However, Diplopoda (Polydesmida) were more associated to the 2.5 Yac area (456 individuals), where a higher bulk and real density were registered. This is in concordance with the significant increase in macrofauna abundance as these variables increase (Table 5). Possibly, these variables are more related to the mineral fraction of the soil, and diplopods using the layer of mixed litter (deposited pine needles and litter of the local vegetation) as refuge and feeding substrate. Our results support this statement because the number of Polydesmids recorded in the 5 Yac area was lower (34 individuals) than in the 2.5 Yac area. Even thougth, both areas presented similar bulk and real densities. Moreover, a decrease in the abundance of this group would indicate a 
decrease in the thickness of the OM layer (heterotrophic phase). These results partially agree with findings of a decline in the diplopod community in areas with 5 years after clearcutting [115]. However, this study did not evaluate areas with less than 5 years after clearcutting, therefore it is not possible to establish if the diplopod community experienced a population explosion as we recorded two years after clearcutting.

Our results suggest that passive restoration of areas where clearcutting of $P$. patula has been carried out is an unviable option, and that at 5 years after clearcut, soil degradation processes may persist or ecological succession may be delayed. These two scenarios could result from vegetation cover removal, direct exposure to sun, wind, and rain, and the arrival of exotic grasses. Accordingly, increases in bacterial and fungal metabolism would result in $\mathrm{OL}$ and $\mathrm{OF}$ layer reductions while increasing the $\mathrm{OH}$ layer, as we observed in the $5 \mathrm{Yac}[19,103,129]$. Furthermore, the isolation of 2.5 and 5 Yac, i.e. the absence of nearby forest patches as propagule sources, is another factor adding to the unviability of passive restoration. The kind of management of leftover $P$. patula plantations and surrounding areas as well as its effects on macrofauna colonization; ought to be evalueated in future studies.

Overall, our findings support previous studies [95, 96, 130, 131], concluding that edaphic macrofauna are more linked to changes in vegetation cover and to quality and quantity of organic matter. Moreover, evidence fom the present study shows that physico-chemical soil features related to OM have an effect on its macrofauna, and that areas with low OL and OF layers can facilitate the establishment of grasslands [107, 108, 132]. The arrival of grasses may be interpreted as an intermediate stage in the ecological succession; however, changes in the spatial location of carbon stocks and evidence about grassland settlement at the beginning of Andean ecosystems degradation, suggest that this hypothesis is unlikely $[43,97,107,133,134]$. Finally, our results support the hypothesis that clearcutting changes the composition of species the function of the ecosystem, leading to random successional trajectories [91]. In our study, these trajectories are determined by the biological offer of nearby areas, and the degradation rate of organic matter. This particularly affects soil macrofauna groups with little mobility, such as Diplopoda and Geophilomorpha, as well as for small-bodied species with specific nutritional diets.

\section{Conclusions}

In comparison to the reference forest, the macrofauna composition changed significantly among areas where clearcutting of exotic species has been carried out. Slope, temperature, bulk density, real density, loam, $\mathrm{PH}, \mathrm{P}, \mathrm{Na}$ and $\mathrm{K}$ 
were the physico-chemical soil variables that better explained the observed soil macrofauna differences. These results also suggest that the maintenance of the OM layer should be taken into account when designing future restoration and conservation plans in areas where clearcutting of exotic species has been implemented. On the other hand, these experimental data did not confirm the hypothesis that the similarity with the native forest patch increases with the age after clearcutting. Moreover, since soil macrofauna indicator species (Ind.Val) differed between study areas, the hypothesis of random successional trajectories may be favoured [91]. However, it is necessary to carry out additional samplings to investigate whether the initial soil communities carry on founder effects that determine their unique long-term assemblies [135]. Alternatively, the observed differences in species composition and structure could be transient, occuring at the onset of successional processes, and ultimately leading to assembly convergence with the time.

This research opens new perspectives for the restoration of high montane forests, showing that the pine needle layer is a relevant element of the ecosystem during the stages following $P$. patula clearcutting. Moreover, this study highlights the importance of different soil macrofauna orders to edaphic processes that will later have an effect on the vegetation. Under the conditions of this study, community assembly analyses based on taxonomic information at the order level proved to be useful to find differences between areas during the early stages of succession; however, analyses carried out at genus or species levels could reveal more detailed patterns. In addition, these results show that groups such as Araneae, Diplopoda, Coleoptera, and even Chilopoda might be useful to monitor and evaluate restoration processes in these areas. Furthermore, counting on species-level information within these orders can help improve the monitoring and diagnosis of these montane forest areas.

\section{Acknowledgements}

This study was supported by the Corporación Autónoma Regional de Cundinamarca (CAR) and a reseach grant from Pontificia Universidad Javeriana (PUJ) to J.I.B-C. and S.B. The authors thank Jessica Rubio for logistic support; Luis Hernández and Fabio Montaño for their field work assistance. The authors acknowledge Dr. Jean-François Ponge and Dr. Alexander Feijoo for helping to identify humus forms and earthworms species, respectively. The authors also thank Dr. Alexander Neita-Moreno for Ancognatha confirmation, Dr. S. Golovatch for Diplopoda Id confirmation, C. Prado, D. Triana and Dr. A. Chagas. Jr for Chilopoda Id confirmation, and Geoffrey Odds for English corrections to this manuscript. 


\section{Conflict of interest}

The authors declare that there are no conflicts of interest.

\section{References}

[1] Richter M. Tropical mountain forests - distribution and general features, in: Gradstein J. Homeier, D. Gansert, Göttingen, The tropical mountain forest: patterns and procces in a biodiversity hotspot Georg-August-Universität, 2008.

[2] Armenteras D, Rodríguez N, Retana J, Morales M. Understanding deforestation in montane and lowland forests of the Colombian Andes, Regional Environmental Change, 11: 693-705, 2011.

doi: 10.1007/s10113-010-0200-y

[3] Allan E, Weisser WW, Fischer M, Schulze ED, Weigelt A, Roscher C, Baade J, Barnard RL, Beßler H, Buchmann N, Ebeling A, Eisenhauer N, Engels C, Fergus AJF, Gleixner G, Gubsch M, Halle S, Klein AM, Kertscher I, Kuu A, Lange M, Le Roux X, Meyer ST, Migunova VD, Milcu A, Niklaus PA, Oelmann Y, Pašalić E, Petermann JS, Poly F, Rottstock T, Sabais ACW, Scherber C, Scherer-Lorenzen M, Scheu S, Steinbeiss S, Schwichtenberg G, Temperton V, Tscharntke T, Voigt W, Wilcke W, Wirth C, Schmid B. A comparison of the strength of biodiversity effects across multiple functions, Oecologia, 173: 223-237, 2013.

doi: 10.1007/s00442-012-2589-0

[4] Balthazar V, Vanacker V, Molina A, Lambin EF. Impacts of forest cover change on ecosystem services in high Andean mountains, Ecological Indicators, 48: 63-75, 2015.

doi: 10.1016/j.ecolind.2014.07.043

[5] Rodríguez N, Armenteras D, Retana J. National ecosystems services priorities for planning carbon and water resource management in Colombia, Land Use Policy, 42: 609-618, 2015.

doi: 10.1016/j.landusepol.2014.09.013

[6] Echeverría C, Smith-Ramírez C, Aronson J, Barrera-Cataño JI. Good news from Latin America and the Caribbean: national and international restoration networks are moving ahead, Restoration Ecology, 23: 1-3, 2015.

doi: $10.1111 /$ rec.12174 
[7] Lal R. Soil Carbon Sequestration Impacts on Global Climate Change and Food Security, Science, 304: 1623-162, 2004.

doi: 10.1126/science.1097396

[8] Armenteras D, Cabrera E, Rodríguez N, Retana J. National and regional determinants of tropical deforestation in Colombia, Regional Environmental Change, 13: 1181-1193, 2013.

doi: 10.1007/s10113-013-0433-7

[9] Cavelier J, Santos C. Efectos de plantaciones abandonadas de especies exóticas y nativas sobre la regeneración natural de un bosque montano en Colombia, Revista de Biología Tropical, 47: 775-784, 1999.

[10] Endo M. CAMCORE: Twelve years of contribution to reforestation in the Andean region of Colombia, Forest Ecology and Management, 63: 219-233, 1994.

doi: 10.1016/0378-1127(94)90112-0

[11] Ponge JF. Plant-soil feedbacks mediated by humus forms: A review, Soil Biology and Biochemistry, 57: 1048-1060, 2013.

doi: 10.1016/j.soilbio.2012.07.019

[12] Zanella A, Jabiol B, Ponge JF, Sartori G, De Waal R, Van Delft B, Graefe U, Cools N, Katzensteiner K, Hager H, Englisch M. A European morpho-functional classification of humus forms, Geoderma, 164: 138-145, 2011.

doi: 10.1016/j.geoderma.2011.05.016

[13] Ponge J, Zanella A, Sartori G, Jabiol B. Terrestrial humus forms: ecological relevance and classification, European Atlas of Soil Biodiversity, European Union, 14-15, 2010.

doi: 10.13140/RG.2.1.3713.5521

[14] Ponge JF. Humus forms in terrestrial ecosystems: A framework to biodiversity, Soil Biology and Biochemistry, 35: 935-945, 2003.

doi: 10.1016/S0038-0717(03)00149-4

[15] Cavelier J, Tobler A. The effect of abandoned plantations of Pinus patula and Cupressus lusitanica on soils and regeneration of a tropical montane rain forest in Colombia, Biodiversity and Conservation, 7: 335-347, 1998.

doi: 10.1023/A:1008829728564 
[16] Loaiza-Usuga JC, León-Peláez JD, González-Hernández MI, Gallardo-Lancho JF, Osorio-Vega W, Correa-Londoño G. Alterations in litter decomposition patterns in tropical montane forests of Colombia: a comparison of oak forests and coniferous plantations, Canadian Journal of Forest Research, 43: 528-533, 2013.

doi: 10.1139/cjfr-2012-0438

[17] Ramírez JA, León-Peláez JD, Craven D, Herrera DA, Zapata CM, González-Hernández MI, Gallardo-Lancho J, Osorio W. Effects on nutrient cycling of conifer restoration in a degraded tropical montane forest, Plant and Soil, 378: 215-226, 2014.

doi: 10.1007/s11104-014-2024-x

[18] León JD, González MI, Gallardo JF. Ciclos biogeoquímicos en bosques naturales y plantaciones de coníferas en ecosistemas de alta montaña de Colombia, Revista de Biologia Tropical, 59: 1883$1894,2011$.

[19] Vera M, Sierra M, Díez M, Sierra C, Martínez A, Martínez FJ, AguilarJ.Deforestation and land use effects on micromorphological and fertility changes in acidic rainforest soils in Venezuelan Andes, Soil and Tillage Research, 97: 184-194, 2007.

doi: 10.1016/j.still.2007.09.015

[20] Eclesia RP, Jobbagy EG, Jackson RB, Biganzoli F, Piñeiro G. Shifts in soil organic carbon for plantation and pasture establishment in native forests and grasslands of South America, Global Change Biology, 18: 3237-3251, 2012.

doi: $10.1111 / j .1365-2486.2012 .02761 . x$

[21] Drewnik M. The effect of environmental conditions on the decomposition rate of cellulose in mountain soils, Geoderma, 132: 116-130, 2006.

doi: 10.1016/j.geoderma.2005.04.023

[22] Goebel MO, Bachmann J, Woche SK, Fischer WR. Soil wettability, aggregate stability, and the decomposition of soil organic matter, Geoderma, 128: 80-93, 2005.

doi: 10.1016/j.geoderma.2004.12.016

[23] Couteaux M, Sarmiento L, Bottner P, Acevedo D, Thiery J. Decomposition of standar plant material along an altitudinal transect $(65-3964 \mathrm{~m})$ in the tropical andes, Soil Biology and Biochemistry, 34: 69-78, 2002. 
[24] Haynes RJ. Nature of the Belowground Ecosystem and Its Development during Pedogenesis, in: Advances in Agronomy, Elsevier, 2014: pp. 43-109.

doi: 10.1016/B978-0-12-800131-8.00002-9

[25] Bardgett RD. The biology of soil: a community and ecosystem approach, Oxford university press, New York USA 2005.

doi: 10.1093/acprof:oso/9780198525035.001.0001

[26] Handa IT, Aerts R, Berendse F, Berg MP, Bruder A, Butenschoen O, Chauvet E, Gessner MO, Jabiol J, Makkonen M, McKie BG, Malmqvist B, Peeters ETHM, Scheu S, Schmid B, Van Ruijven J, Vos VCA, Hättenschwiler S. Consequences of biodiversity loss for litter decomposition across biomes, Nature, 509: 218-21, 2014.

doi: 10.1038/nature13247

[27] Brose U, Scheu S. Into darkness: unravelling the structure of soil food webs, Oikos, 123: 1153-1156, 2014.

doi: 10.1111/oik.01768

[28] Wardle DA, Yeates GW, Barker GM, Bonner KI. The influence of plant litter diversity on decomposer abundance and diversity, Soil Biology and Biochemistry, 38: 1052-1062, 2006.

doi: 10.1016/j.soilbio.2005.09.003

[29] Lavelle P. Faunal activities and soil processes: adaptative strategy that determine ecosystem function, 27: 93-132,1997.

doi: 10.1016/S0065-2504(08)60007-0

[30] Wickings K, Grandy AS, Reed SC, Cleveland CC. The origin of litter chemical complexity during decomposition, Ecology Letters, 15: 1180-1188, 2012.

doi: 10.1111/j.1461-0248.2012.01837.x

[31] Wickings K, Grandy AS. Management intensity interacts with litter chemistry and climate to drive temporal patterns in arthropod communities during decomposition, Pedobiologia, 56: 105-112, 2013. doi: 10.1016/j.pedobi.2013.01.001

[32] Wickings K, Grandy AS, Reed S, Cleveland C. Management intensity alters decomposition via biological pathways, Biogeochemistry, 104: 365-379, 2011.

doi: 10.1007/s10533-010-9510-x 
[33] Kibblewhite MG, Ritz K, Swift MJ. Soil health in agricultural systems. Philosophical Transactions of the Royal Society of London. Series B, Biological Sciences, 363: 685-701, 2008.

doi: $10.1098 /$ rstb.2007.2178

[34] Moreira FM. Manual de biología de suelos tropicales, Earthscan, Coyoacan Mexico 2012.

[35] Wall DH, Bardgett RD, Behan-Pelletier V, Herrick JE, Jones TH, Six J, Strong DR. Soil ecology and ecosystem services, Oxford, New York USA 2012.

[36] Wardle DA. Communities and ecosystems-linking the aboveground and belowground components. Princeton University, New Jersey, USA 2002.

[37] De Deyn GB, Van Ruijven J, Raaijmakers CE, De Ruiter PC, Van Der Putten WH. Above and belowground insect herbivores differentially affect soil nematode communities in species-rich plant communities, Oikos, 116: 923-930, 2007.

doi: 10.1111/j.2007.0030-1299.15761x

[38] Carbajo V, den Braber B, van der Putten WH, De Deyn GB. Enhancement of late successional plants on ex-arable land by soil inoculations, PLoS ONE, 6: 2011.

doi: 10.1371/journal.pone.0021943

[39] De Deyn GB, Raaijmakers CE, Zoomer HR, Berg MP, De Ruiter PC, Verhoef HA, Bezemer TM, Van der Putten WH. Soil invertebrate fauna enhances grassland succession and diversity, Nature, 422: 711-713, 2003.

doi: 10.1038/nature01548

[40] Rousseau L, Fonte SJ, Téllez O, van der Hoek R, Lavelle P. Soil macrofauna as indicators of soil quality and land use impacts in smallholder agroecosystems of western Nicaragua, Ecological Indicators, 27: 71-82, 2013.

doi: 10.1016/j.ecolind.2012.11.020

[41] Cluzeau D, Guernion M, Chaussod R, Martin-Laurent F, Villenave C, Cortet J, Ruiz-Camacho N, Pernin C, Mateille T, Philippot L, Bellido A, Rougé L, Arrouays D, Bispo A, Pérès G. Integration of biodiversity in soil quality monitoring: Baselines for microbial and soil fauna parameters for different land-use types, European Journal of Soil Biology, 49: 63-72, 2012.

doi: 10.1016/j.ejsobi.2011.11.003 
[42] Paquin P, Coderre D. Deforestation and fire impact on edaphic insect larvae and other macroarthropods, Environmental Entomology, 26: $21-30,1997$.

[43] Hedlund K, Griffiths B, Christensen S, Scheu S, Setälä H, Tscharntke T, Verhoef H. Trophic interactions in changing landscapes: Responses of soil food webs, Basic and Applied Ecology, 5: 495-503, 2004.

doi: $10.1016 /$ j.baae.2004.09.002

[44] Frouz J, Prach K, Pižl V, Háněl L, Starý J, Tajovský K, Materna J, Balík V, Kalčík J, Řehounková K. Interactions between soil development, vegetation and soil fauna during spontaneous succession in post mining sites, European Journal of Soil Biology, 44: 109-121, 2008.

doi: 10.1016/j.ejsobi.2007.09.002

[45] Frouz J, Thébault E, Pižl V, Adl S, Cajthaml T, Baldrián P, Háněl L, Starý J, Tajovský K, Materna J, Nováková A, De Ruiter PC. Soil Food Web Changes during Spontaneous Succession at Post Mining Sites: A Possible Ecosystem Engineering Effect on Food Web Organization?, PLoS ONE, 8: e79694, 2013.

doi: 10.1371/journal.pone.0079694

[46] Meloni F, Varanda EM. Litter and soil arthropod colonization in reforested semi-deciduous seasonal Atlantic forests, Restoration Ecology, 23: 690-697, 2015.

doi: $10.1111 /$ rec.12236

[47] Van der Putten WH, Bardgett RD, de Ruiter PC, Hol WHG, Meyer KM, Bezemer TM, Bradford MA, Christensen S, Eppinga MB, Fukami T, Hemerik L, Molofsky J, Schädler M, Scherber C, Strauss SY, Vos M, Wardle DA. Empirical and theoretical challenges in aboveground-belowground ecology, Oecologia, 161: 1-14, 2009.

doi: $10.1007 /$ s00442-009-1351-8

[48] Kostenko O, van de Voorde TFJ, Mulder PPJ, Van der Putten WH, Martijn Bezemer T. Legacy effects of abovegroundbelowground interactions, Ecology Letters, 15: 813-821, 2012.

doi: 10.1111/j.1461-0248.2012.01801.x

[49] Kardol P, Wardle DA. How understanding abovegroundbelowground linkages can assist restoration ecology, Trends in Ecology and Evolution, 25: 670-679, 2010.

doi: 10.1016/j.tree.2010.09.001 
[50] Stanturf JA, Palik BJ, Dumroese RK. Contemporary forest restoration: A review emphasizing function, Forest Ecology and Management, 331: 292-323, 2014.

doi: 10.1016/j.foreco.2014.07.029

[51] Camero É, Diaz JE, Salinas A. Estudio de la artropofauna asociada a suelos de dos tipos de ecosistemas en la cuenca del río Cauca - Colombia, Acta Biologica Colombiana, 10: 35-44, 2005.

[52] Ruiz-Cobo HD, Feijoo A, Rodriguez C, Comunidades de macroinvertebrados edáficos en diferentes sistemas de uso del terreno en la cuenca del río Otún - Colombia, Acta Zoologica Mexicana, Numero esp: 165-178, 2010.

[53] Kattan GH, Correa D, Escobar F, Medina C. Leaf-litter arthropods in restored forests in the Colombian Andes: A comparison between secondary forest and tree plantations, Restoration Ecology, 14: 95-102, 2006.

doi: 10.1111/j.1526-100X.2006.00109.x

[54] Cerón P, Montenegro S, Noguera E. Macrofauna en suelos de Bosque y Pajonal de la reserva natural Pueblo Viejo, Nariño, Colombia, Revista de la Academia Colombiana de Ciencias Exactas, Físicas y Naturales, 32: 447-453, 2008.

http://www.accefyn.org.co/revista/Vol_32/125/447-453.pdf

[55] Feijoo A, Quintero H, Fragoso CE. Earthworm communities in forest and pastures of the Colombian Andes, Caribbean Journal of Science, 42: 301-310, 2006.

[56] Feijoo A, Lavelle P. Relationships between land use and the earthworm communities in the basin of La Vieja river, Colombia, Pastos y Forrajes, 30: 235-249, 2015.

[57] Feijoo A, Carvajal AF, Zúñiga MC, Quintero H, Fragoso C. Diversity and abundance of earthworms in land use systems in central-western Colombia, Pedobiologia, 54: S69-S75, 2011.

doi: 10.1016/j.pedobi.2011.09.016

[58] Feijoo AM, Knapp EB, Lavelle P, Moreno AG. Quantifying soil macrofauna in a Colombian watershed, Pedobiologia, 43: 513-517, 1999.

[59] León-gamboa AL, Ramos C, García MR. Efecto de plantaciones de pino en la artropofauna del suelo de un bosque Altoandino, Revista de Biologia Tropical, 58: 1031-1048, 2010. 
[60] USDA. Soil Taxonomy, Geological Magazine, 114: 492, 1999. doi: 10.1017/S0016756800045489

[61] Bockheim JG, Gennadiyev AN, Hartemink AE, Brevik EC. Soil-forming factors and Soil Taxonomy, Geoderma, 226-227: 231$237,2014$.

[62] Kotschwar A. Plan de manejo de la Cuenca del embalse de Neusa. Corporación auntónoma de la Sabana de Bogotá y de los Valles de Ubaté y Chiquinquirá. Bogotá, Colombia, 1980.

[63] Anderson J, Ingram J. Tropical Soil Biology and Fertility: A Handbook of Methods, Oxfordshire: CAB international, United Kingdom, 1993.

[64] Adis J, ed. Amazonian Arachnida and Myriapoda, Pensoft Publishers, Sofia-Moscow, 2002.

[65] Golovatch S, Wytwer J. The South American Millipede Genus Phaneromerium Verhoeff, 1941. With the Description of a New Cavernicolousspecies From Brazil (Diplopoda: Polydesmida: Fuhrmannodesmidae), Annales Zoologici (Warzawa), 54: 511-514, 2004.

[66] Schileyko A. A new species of Newportia Gervais, 1847 from Puerto Rico, with a revised key to the species of the genus (Chilopoda, Scolopendromorpha, Scolopocryptopidae), Zookeys, 276: 39-54, 2013.

doi: $10.3897 /$ zookeys.276.4876

[67] Pereira LA. A new schendylid centipede (Myriapoda: Chilopoda: Geophilomorpha) from the Bolivian Amazon Forest, Zootaxa, 3905: 1-26, 2015.

doi: 10.11646/zootaxa.3905.1.1

[68] Guzmán De Tomé ME. Clave de las especies de Conoderus Grupo II (Coleoptera: Elateridae), Revista de la Sociedad Entomológica de Argentina, 64: 119-129, 2005.

[69] Carl J. Diplopoden von columbien, Mémoires de la Société des Sciences Naturelles de Neuchâtel, 821-993, 1914.

https://www.biodiversitylibrary.org/bibliography/10027\#/summary

[70] Arnett Jr. R, Thomas M, Skelley P, Frank J. American Beetles, Vol. 2: Polyphaga: Scarabaeoidea through Curculionoidea, CRC Press, Boca Raton, USA, 2002. 
[71] Carvazos T. Manual de prácticas de física de suelos, Trillas, Mexico D.F, 1992.

[72] IGAC, Suelos de Colombia, IGAC, Bogota D.C., Colombia, n.d.

[73] Flint A, Flint L. Particle density, in: D. Dane, G. Topp (Eds.), Methods Soil Anal. Part 4. Physical. Minearological Methods, 2nd edition, American society of agronomy and soil science society of America, Madison, Wisconsin, USA, pp. 235-240, 2002.

[74] Blake G, Hartge K. Particle-size analysis, in: L. Page, R. Miller, D. Keeney (Eds.), Methods Soil Anal. Part 1 Phys. Minearological Methods, second, American society of agronomy and soil science society of America, Madison, Wisconsin, USA, 1997.

[75] Sheldric B, Wang C. Particle size distribution, in: M. Carter (Ed.), Soil Sampling. Methods Analisys. Lewis publisher, Boca Raton, USA, 499-511, 1993.

[76] Codazzi IGA. Métodos analíticos del laboratorio de suelos, sexta edic, Imprenta Nacional de Colombia, Bogota D.C., Colombia, 2006.

[77] Walkley A, Black IA. An examination $f$ the Degtjareff method for determining soil organic matter, and a proposed modification of the chromic acid titration method, Soil Science, 37: 29-38, 1934.

doi: 10.1097/00010694-193401000-00003

[78] Hendershot W, Lalande H, Duquette M. Ion exchange and exchangeable cations, in: M. Carter (Ed.), Soil Sampl. Methods Anal, Lewis publisher, Boca Raton, USA, 162-177, 1993.

[79] Dufrene M, Legendre P. Species Assemblages and Indicator Species: the need for a flexible asymetrical approach, Ecological Monographs, 67: 345-366, 1997.

[80] Roberts DW. Ordination and Multivariate Analysis for Ecology, 21-51, 2016.

https://cran.r-project.org/web/packages/labdsv/labdsv.pdf

[81] R Development Core Team, R: A language and environment for statistical computing, R Foundation for Statistical Computing, Vienna, Austria, 2016.

http://www.r-project.org 
[82] McArdle BH, Anderson MJ. Fitting multivariate models to community data: A comment on distance-based redundancy analysis, Ecology, 2001.

doi: 10.1890/0012-9658(2001)082[0290:FMMTCD]2.0.CO;2

[83] Kindt R, Coe R. Tree diversity analysis, 2005.

doi: 10.1198/tas.2008.s264

[84] Warton DI. Many zeros does not mean zero inflation: Comparing the goodness-of-fit of parametric models to multivariate abundance data, Environmetrics, 2005.

doi: $10.1002 /$ env.702

[85] Wang Y, Naumann U, Wright ST, Warton DI. Package "mvabund": Statistical methods for analysing multivariate abundance data, 2013.

[86] Imdadullah M, Aslam M, Altaf S. mctest: An $\{R\}$ Package for Detection of Collinearity Among Regressors, R J. 2016.

[87] Villani MG, Allee LL, Díaz A, Robbins PS. Adaptive strategies of edaphic arthropods, Annual Review of Entomology, 44: 233-256, 1999. doi: 10.1146/annurev.ento.44.1.233

[88] Schowalter TD. Insect Responses to Major Landscape-Level Disturbance, Annual Review of Entomology, 57: 1-20, 2012.

doi: 10.1146/annurev-ento-120710-100610

[89] Neita-Moreno JC, Morón MA. Estados inmaduros de Ancognatha ustulata (Coleoptera: Melolonthidae: Dynastinae: Cyclocephalini), Revista Mexicana de Biodiversidad, 79: 355-361, 2008.

[90] Kalinkat G, Jochum M, Brose U, Dell AI. Body size and the behavioral ecology of insects: linking individuals to ecological communities, Current Opinion in Insect Science, 9: 24-30, 2015.

doi: 10.1016/j.cois.2015.04.017

[91] Heikkala O, Seibold S, Koivula M, Martikainen P, Müller J, Thorn S, Kouki J. Retention forestry and prescribed burning result in functionally different saproxylic beetle assemblages than clear-cutting, Forest, Ecology and. Management, 359: 51-58, 2016.

doi: 10.1016/j.foreco.2015.09.043 
[92] Ponge JF. Succession of fungi and fauna during decomposition of needles in a small area of Scots pine litter, Plant and Soil. 138: 99-113, 1991.

doi: 10.1007/BF00011812

[93] Hättenschwiler S, Tiunov AV, Scheu S. Biodiversity and Litter Decomposition in Terrestrial Ecosystems, Annual Review of Ecology, Evolution and Systematics, 36: 191-218, 2005.

doi: 10.1146/annurev.ecolsys.36.112904.151932

[94] Bormann BT, Darbyshire RL, Homann PS, Morrissette BA, Little SN. Managing early succession for biodiversity and longterm productivity of conifer forests in southwestern Oregon, Forest Ecology Management, 340: 114-125, 2015.

doi: 10.1016/j.foreco.2014.12.016

[95] Vasconcellos RLF, Segat JC, Bonfim JA, Baretta D, Cardoso EJBN. Soil macrofauna as an indicator of soil quality in an undisturbed riparian forest and recovering sites of different ages, European Journal of Soil Biology and Biochemistry. 58: 105-112, 2013. doi: 10.1016/j.ejsobi.2013.07.001

[96] Amazonas NT, Viani RAG, Rego MGA, Camargo FF, Fujihara RT, Valsechi OA. Soil macrofauna density and diversity across a chronosequence of tropical forest restoration in Southeastern Brazil, Brazilian journal of biology, 1-8, 2018.

[97] Tapia-Armijos MF, Homeier J, Ivan Espinosa C, Leuschner C, de la Cruz M. Deforestation and Forest Fragmentation in South Ecuador since the 1970s-Losing a Hotspot of Biodiversity, PLoS ONE. 10: 1-19, 2015.

doi: $10.1371 /$ journal.pone.0133701

[98] Tilman D, Isbell F, Cowles JM. Biodiversity and Ecosystem Functioning, Annual Review of Ecology, Evolution and Systematics, 45: 471-493, 2014.

doi: 10.1146/annurev-ecolsys-120213-091917

[99] Trap J, Bureau F, Brethes A, Jabiol B, Ponge JF, Chauvat M, Decaëns T, Aubert M. Does moder development along a pure beech (Fagus sylvatica L.) chronosequence result from changes in litter production or in decomposition rates?, Soil Biology and Biochemistry, 43: 1490-1497, 2011.

doi: 10.1016/j.soilbio.2011.03.025 
[100] Zanella A, Jabiol B, Ponge JF, Sartori G, De Waal R, Van Delf B, Graefe U, Cools N, Katzensteiner K, Hager H, English M, Brethes A. Toward an European Humus forms Reference Base, Studi trentini di scienze naturali. 85: 145-151, 2009.

[101] Paillet Y, Bergès L, HjÄltén J, Ódor P, Avon C, BernhardtRömermann M, Bijlsma RJ, De Bruyn L, Fuhr M, Grandin U, Kanka R, Lundin L, Luque S, Magura T, Matesanz S, Mészáros I, SebastiÀ MT, Schmidt W, Standovár T, Tothmérész B, Uotila A, Valladares F, Vellak K, Virtanen R. Biodiversity differences between managed and unmanaged forests: Meta-analysis of species richness in Europe, Conservation Biology, 24: 101-112, 2010. doi: 10.1111/j.1523-1739.2009.01399.x

[102] Sylvain ZA, Wall DH. Linking soil biodiversity and vegetation: Implications for a changing planet, American Journal of Botany, 98: 517-527, 2011.

doi: $10.3732 /$ ajb.1000305

[103] Paul EA. The nature and dynamics of soil organic matter: Plant inputs, microbial transformations, and organic matter stabilization, Soil Biology and Biochemistry, 98: 109-126, 2016.

[104] Hostacka A, Ciznar I, Stefkovicova M. Temperature and pH affect the production of bacterial biofilm, Folia Microbiologica, 55(1): 75-78, 2010.

doi: 10.1007/s12223-010-0012-y

[105] Podgaiski LR, Rodrigues GG. Leaf-litter decomposition of pioneer plants and detritivore macrofaunal assemblages on coal ash disposals in southern Brazil, European Journal of Soil Biology, 46: 394-400, 2010.

doi: 10.1016/j.ejsobi.2010.09.001

[106] Ponge JF. Humus and time: a love story, Hal. 2010.

doi: 10.13140/RG.2.1.1354.2561

[107] Tonneijck FH, Jongmans AG. The influence of bioturbation on the vertical distribution of soil organic matter in volcanic ash soils: A case study in northern Ecuador, European Journal of Soil Science, 59: 1063-1075, 2008.

doi: 10.1111/j.1365-2389.2008.01061.x 
[108] Jiménez JJ, Lal R. Mechanisms of C Sequestration in Soils of Latin America, CRC, Critical Reviews in Plant Science, 25: 337-365, 2006.

doi: 10.1080/0735268060094240

[109] Corrales A, Duque A, Uribe J, Londoño V. Abundance and diversity patterns of terrestrial bryophyte species in secondary and planted montane forests in the northern portion of the Central Cordillera of Colombia, Bryologist, 113: 8-21, 2010.

doi: 10.1639/0007-2745-113.1.8

[110] De Lima SS, de Aquino AM, Leite LFC, Velásquez E, Lavelle P. Relação entre macrofauna edáfica e atributos químicos do solo em diferentes agroecossistemas, Pesquisa Agropecuaria Brasileira, 45: 322-331, 2010.

doi: 10.1590/S0100-204X2010000300013

[111] Ott D, Digel C, Klarner B, Maraun M, Pollierer M, Rall BC, Scheu S, Seelig G, Brose U. Litter elemental stoichiometry and biomass densities of forest soil invertebrates, Oikos, 1212-1223, 2014.

doi: 10.1111/oik.01670

[112] Feijoo A, Quintero H, Fragoso C, Moreno A. Patrón de distribución y listado de especies de las lombrices de tierra (Annelida, Oligochaeta) en Colombia, Acta Zoologica Mexicana, 20: 197-220, 2004.

[113] Feijoo A, Zuñiga MC, Quintero H, Carvajal-Vanegas AF, Ortiz DP. Patrones de asociación entre variables del suelo y usos del terreno en la cuenca del río La Vieja, Colombia, Acta Zoologica Mexicana, Numero especial: 151-164, 2010.

[114] Grove SJ. Saproxylic Insect Ecology and the Sustainable Management of Forests, Annual Review of Ecology and Systematics, 33: 1-23, 2002.

doi: 10.1146/annurev.ecolsys.33.010802.150507

[115] Frouz J, Roubíčková A, Heděnec P, Tajovský K. Do soil fauna really hasten litter decomposition? A meta-analysis of enclosure studies, European Journal of Soil Biology, 68: 18-24, 2015.

doi: 10.1016/j.ejsobi.2015.03.002 
[116] Zhang DQ, Hui DF, Luo YQ, Zhou GY. Rates of litter decomposition in terrestrial ecosystems: global patterns and controlling factors, Journal of Plant Ecology-Uk, 1: 85-93, 2008.

doi: 10.1093/Jpe/Rtn002

[117] Eisenhauer N, Milcu A, Sabais ACW, Bessler H, Brenner J, Engels C, Klarner B, Maraun M, Partsch S, Roscher C, Schonert F, Temperton V,M, Thomisch K, Weigelt A, Weisser WW, Scheu S. Plant diversity surpasses plant functional groups and plant productivity as driver of soil biota in the long term, PLOS ONE, 6: 15-18, 2011.

doi: 10.1371/journal.pone.0016055

[118] Bezemer TM, Fountain MT, Barea JM, Christensen S, Dekker SC, Duyts H, Van Hal R, Harvey J, Maraun M, Mikola J, Mladenov G, Robin C, De Ruiter PC, Scheu S, Setälä H, Smilauer P, Van Der Putten WH. Divergent composition but similar function of soil food webs beneath individual plants: plant species and community effects, Ecology, 91: 3027-3036, 2010.

doi: 10.1890/09-2198.1

[119] Ruiz-Cobo DH, Bueno-Villegas J, Feijoo-Martinez A. Land use and alpha, beta, and gamma diversity of Diplopoda in the Otún basin, Colombia, Universitas scientiarum, 15(1): 59-67, 2010.

doi: 10.11144/javeriana.SC15-1.luaa

[120] Johansson T, Hjältén J, Olsson J, Dynesius M, Roberge JM. Long-term effects of clear-cutting on epigaeic beetle assemblages in boreal forests, Forest Ecology and Management. 359: 65-73, 2016.

doi: 10.1016/j.foreco.2015.09.041

[121] Del Río MG, Malvardi AE, Lanteri A. Systematics and cladistics of a new naupactini genus (Coleoptera: Curculionidae: Entiminae) from the Andes of Colombia and Ecuador, Zoological Journal of the Linnean Society, 166: 54-71, 2012.

doi: 10.1111/j.1096-3642.2012.00833.x

[122] Lanteri A, Guedes J, Parra J. Weevils injurious for roots of citrus in São Paulo State, Brazil, Neotropical Entomology, 31(4): 561-569, 2002.

doi: 10.1590/S1519-566X2002000400008 
[123] Aguirre-Tapiero MDP. Clave de identificación de géneros conocidos y esperados de Elateridae Leach (Coleoptera: Elateroidea) en Colombia, Boletín del Museo de Entomología de la Universidad del Valle, 10: 25-35, 2009.

http://entomologia.univalle.edu.co/boletin/4Aguirre.pdf

[124] Decaëns T, Mariani L, Lavelle P. Soil surface macrofaunal communities associated with earthworm casts in grasslands of the Eastern Plains of Colombia, Applied Soil Ecology, 13: 87-100, 1999.

doi: 10.1016/S0929-1393(99)00024-4

[125] Florez E. Las arañas del departamento del Valle del Cauca: Un manual introductorio a su diversidad y clasificación. 1996.

doi: 10.4067/S0071-17132000003500023

[126] Minelli A. The Myriapoda Treatise on Zoology - Anatomy, Taxonomy, Biology, Volumen 1, Brill, Leiden - Boston, 2011.

doi: 10.1163/9789004188266

[127] Adis J. Amazonian Arachnida and Myriapoda, Pensoft Publishers, Sofia-Moscow, 2002.

[128] Hembree DI. Neoichnology of burrowing millipedes: Linking modern burrow morphology, organism behavior, and sediment properties to interpret continental ichnofossils, Palaios, 24: 425-439, 2009.

doi: 10.2110/palo.2008.p08-098r

[129] Chacón G, Gagnon D, Paré D. Comparison of soil properties of native forests, Pinus patula plantations and adjacent pastures in the Andean highlands of southern Ecuador: Land use history or recent vegetation effects?, Soil Use and Management, 25: 427-433, 2009.

doi: 10.1111/j.1475-2743.2009.00233.x

[130] Barnes AD, Jochum M, Mumme S, Haneda NF, Farajallah A, Widarto TH, Brose U. Consequences of tropical land use for multitrophic biodiversity and ecosystem functioning, Nature Communications, 5: 1-7, 2014.

doi: 10.1038/ncomms6351 
[131] Mumme S, Jochum M, Brose U, Haneda NF, Barnes AD. Functional diversity and stability of litter-invertebrate communities following land-use change in Sumatra, Indonesia, Biological Conservation, 191: 750-758, 2015.

doi: 10.1016/j.biocon.2015.08.033

[132] Jobbágy EG, Jackson RB. The vertical distribution of soil organic carbon and its relation to climate and vegetation, Ecological Applications, 10: 423-436, 2000.

doi: 10.1890/1051-0761(2000)010[0423:TVDOSO]2.0.CO;2

[133] Homeier J, Leuschner C, Bräuning A, Cumbicus NL, Hertel D, Martinson GO, Spannl S, Veldkamp E. Ecosystem Services, Biodiversity and Environmental Change in a Tropical Mountain Ecosystem of South Ecuador, Springer-Verlag, Berlin Heidelberg, 2013.

doi: 10.1007/978-3-642-38137-9

[134] Gunaratne AMT, Gunatilleke CVS, Gunatilleke IA, Madawala HMSP, Burslem DFRP. Overcoming ecological barriers to tropical lower montane forest succession on anthropogenic grasslands: Synthesis and future prospects, Forest Ecology and Management, 329: 340-350, 2014.

doi: 10.1016/j.foreco.2014.03.035

[135] Weslien J, Djupström LB, Schroeder M, Widenfalk O. Long-term priority effects among insects and fungi colonizing decaying wood, Journal of Animal Ecology, 80: 1155-1162, 2011.

doi: 10.1111/j.1365-2656.2011.01860.x 


\section{Macrofauna edáfica en áreas con diferentes edades después de la tala rasa de Pinus patula}

Resumen. El establecimiento de plantaciones forestales de especies exóticas cambia el ambiente edáfico y la biodiversidad del suelo, y es una de las mayores amenazas para el bosque de alta montaña. La macrofauna edáfica es un indicador de los procesos sucesionales del ecosistema y, consecuentemente, puede tener un rol importante en la restauración ecológica tras el proceso de tala rasa de estas plantaciones. El objetivo de este trabajo fue entender cómo la macrofauna cambia en áreas con diferentes edades después de la tala rasa de Pinus patula, e identificar las variables fisicoquímicas que mejor explican estas variaciones. Se evaluó la macrofauna en un bosque de alta montaña junto con tres áreas con diferentes edades después de la tala: $0,2.5$ y 5 años. También se evaluó el efecto de las características fisicoquímicas del suelo en la abundancia de macrofauna. La composicion de la macrofauna cambió después de la tala rasa. La abundancia, riqueza y diversidad fueron menores a la edad 0 después de la tala rasa que a las otras edades. Ademas, la similitud con el bosque de referencia no aumentó con el tiempo después de la tala, por los cambios en las características del suelo que ocurren como consecuencia de la tala. La pendiente, la temperatura, la densidad aparente, la densidad real, la textura del suelo, $\mathrm{pH}, \mathrm{P}, \mathrm{Na}$ y $\mathrm{K}$ tuvieron un efecto positivo en la abundancia de macrofauna. Estas variables fisicoquímicas deberían considerarse en el diseño de los planes de restauración de los ecosistemas de bosque andino. Además, Diplopoda, Coleoptera y Chilopoda podrían ser útiles para monitorear y evaluar los procesos de restauración después de la tala de Pinus spp., dada su alta abundancia, diversidad y relación con condiciones ambientales.

Palabras clave: Andes; bosque tropical de montaña; ecología de la restauración; macrofauna edáfica. 


\section{Macrofauna do solo em áreas com diferentes Idades após o corte raso de Pinus patula}

Resumo. As florestas de árvores exóticas alteram as dinâmicas e biodiversidade do solo nas áreas andinas de alta montanha. A macrofauna do solo atua como indicador do processo de sucessão dos ecossistemas e pode ter um papel importante nos processos de restauração ecológica após o corte raso de plantações de árvores exóticas. O objetivo deste estudo foi entender como mudam as associações entre a macrofauna do solo em áreas com diferentes idades após o corte raso do pinheiro, Pinus patula, e identificar variáveis físico-químicas do solo que explicassem essas diferenças. Para isso avaliamos a macrofauna de uma floresta de alta montanha assim como a de três áreas com diferentes idades após o corte raso: 0; 2.5 e 5 anos após o corte raso (Yac). Também avaliamos o efeito das variáveis físico-químicas do solo na abundância da macrofauna. A composição da macrofauna mudou após o cote raso. A abundância, riqueza e diversidade da macrofauna foram menores na área com 0 Yac do que em outras áreas. Adicionalmente, a similaridade da macrofauna com a floresta de referência não aumentou em função dos anos após o corte raso. Isto é devido a mudanças nas características do solo desencadeadas pelo corte raso. A inclinação, temperatura, densidade aparente, densidade real, limo, $\mathrm{pH}, \mathrm{P}, \mathrm{Na}$ e $\mathrm{K}$ foram as variáveis do solo que tiveram um efeito positivo na abundância da macrofauna. Estas variáveis físico-químicas deveriam ser consideradas no projeto de planos de restauração para ecossistemas de floresta andinos. Adicionalmente, as ordens Diplopoda, Coleoptera e Chilopoda podem ser úteis para monitorar e avaliar o processo de restauração após o corte raso de Pinus spp. devido a sua alta abundância, diversidade e relação com as condições ambientais.

Palavras-chave: Andes; floresta tropical de montanha; ecologia da restauração; macrofauna do solo. 


\section{Esteban Tulande-M}

Is a graduate student in Biology at Pontificia Universidad Javeriana, and in natural resource management at Universidad Militar Nueva Granada. His graduate research focused on the use of soil and water macroinvertebrates as bioindicators. He is currently working as a research assistant for the School of Ecological Restoration. His current interests are focused on the study soil fauna and its application in restoration ecology.

\section{José Ignacio Barrera Cataño}

He is Associate Professor in the Department of Biology, Faculty of Sciences, at Pontificia Universidad Javeriana. His doctoral thesis, at The University of Barcelona, was about the ecological restoration of high Andean forests under anthropogenic pressure. Since 2002, he has been the director of the School of Ecological Restoration. His research interest is about how to neutralize environmental stressors to accelerate the process of succession and, recover lost attributes of agroecosystems.

\section{Carlos Eduardo Alonso-Malaver}

He is associated professor of the Department of Statistics, Faculty of Sciences, at Universidad Nacional de Colombia. His doctoral internship, led by Dr. Emilio Porcu - Italy -, was dedicated to present theoretical support for radial space-time covariance functions. Since 2000 he have been in contact with School of Ecological Restoration. His research focus on statistical modelling and restoration ecology, space-time modelling and identification and monitoring of bio-indicators of restoration.

\section{Carlos Fabián Morantes-Ariza}

Is a Biologist from the Universidad Nacional de Colombia. His main area of interest is the Evolution of Ecological Interactions. Currently he works as a part time Researcher and Professor at Pontificia Universidad Javeriana and as a researcher in the Evolutionary Ecology lab at the Universidad Nacional de Colombia.

\section{Sofía Isabel Basto Mercado}

She is Associate Professor in the Department of Biology, Faculty of Sciences, at Pontificia Universidad Javeriana. She received her PhD from The University of Sheffield (England). Her research interests lie within soil ecology, seed and seedling ecophysiology. Specifically, she is focused on understanding the response of seeds and seedlings to anthropogenic disturbances and climate change and, the implications of these responses in the dynamic processes of vegetation and ecological restoration. 